\title{
TO INDIANER-BIBLER \\ I DET KONGELIGE BIBLIOTEK
}

\section{ET BIDRAG TIL NORDAMERIKAS ELDSTE BOGHISTORIE}

AF

\author{
Palle Birkelund
}

$\mathrm{D}$

en spanske armadas totale nederlag $\mathrm{I} 588 \mathrm{i}$ farvandene omkring Storbritannien skabte baggrunden for en effektiv engelsk kolonisering af Nordamerika. Nu kunne briterne satte magt bag deres nasten århundredgamle krav om en højhedsret over den nordamerikanske østkyst, og de var ikke sene til at udnytte den nye storpolitiske magtfordeling. Selv om flere koloniseringsforsøg slog fejl og forårsagede store tab af menneskeliv og kapital, gav man ikke op. I6o6 oprettedes to handelskompagnier, hvoraf det ene naste år etablerede en koloni på den del af kysten, som søhelten Walter Raleigh, den romantiske og tragiske skikkelse i kampen for Englands storhed, havde givet navnet Virginia, og til trods for store tab og megen modgang bed man sig så godt fast, at det ikke lykkedes hverken indianerne eller sulten at fâ bugt med de nyankomne briter. Efter at man havde lart at tilberede tobakken og fået sat en eksport igang gik det fremad, og allerede i 1624 blev Virginia en kronkoloni.

Tyngdepunktet for den engelske kolonisering af Nordamerika kom dog til at ligge langt nordligere end Virginia, og det store år i Amerikas historie er da også 1620 . I det år, få dage for juleaften, stæunede det engelske skib Mayflower, efter i over to måneder at have kampet sig frem over Nordatlanten, ind mod kysten ved Cape Cod i Massachusetts. Fra det nu så berømte skib gik 102 målbevidste, ja næsten fanatiske nybyggere, de såkaldte „Pilgrim Fathers" $\mathrm{i}$ land på et sted, de kaldte Plymouth, og en ny epoke i Amerikas historie blev indledet. De nyankomne var solide mellemstandsfolk, handlende, håndværkere eller universitetsuddannede folk, der havde forladt deres hjemland for uhin- 
dret at kunne begynde en ny tilvarelse og skabe et nyt samfund i den ånd, der for dem var den eneste rigtige, den puritanske. Et teokratisk samfund indrettet efter visse republikansk-demokratiske principper var det ideal, de med stor energi og udholdenhed gik i gang med at virkeliggøre; men egentlige demokrater var de ikke, og nogen afvigelse fra den puritanske tro tåltes ikke. Der blev brug for al kraft og sejghed; allerede den forste vinter bukkede halvdelen af nybyggerne under, men vanskelighederne blev overvundet, og strommen af englændere, der af politiske, religiøse eller okonomiske grunde så deres fremtid bedre sikret i det fremmede og forlod hjemlandet, voksede i hastig takt. ${ }^{6} 628$ grundlagdes. kolonien Salem, I630 Boston, og på det tidspunkt var der ca. 7000 engelske kolonister på det nordamerikanske fastland; et tiår senere var tallet vokset til over 20.000 , hvortil kom mindst det dobbelte antal, som havde slået sig ned på de vestindiske øer og på Bermuda. Med undtagelse af små områder, der var i hænderne på svenskere og hollændere, var hele kysten fra Maine til Carolina i engelsk besiddelse.

De religiøse, økonomiske og politiske forhold vekslede starkt fra sted til sted, men kraftcentret kom som navnt til at ligge mod nord, ikke mindst efter at kolonierne Plymouth, Massachusetts, New Haven og Connecticut i 1642 dannede forbundet "The United Colonies of New England“.

Vanskeligheder var der nok af, religiøse og sociale stridigheder hæmmede udviklingen, men det gik fremad; mange idealer måtte gang pâ gang lide nederlag, men der skabtes $\mathrm{i}$ de ugastmilde egne livssyn og samfundsformer, der den dag i dag præger "the American Way of Life".

Nybyggerne tog meget af det gamle England med sig over Atlanten, men de onskede at skabe et nyt England, og hertil behøvedes naturligvis foruden kirker og skoler også universiteter og anden immateriel kultur, eller som det blev udtrykt $i$ et anonymt skrift fra I $\left._{4} 3^{1}\right)$ : „After God had carried us safe to New England, and wee had builded our houses, provided necessaries for our liveli-hood, rear'd convenient places for Gods worship, and setled the Civil Government: One of the next things we longed for, and looked after was to advance Learning ....".

Allerede i 1638 kunne man da også i Newtown tæt uden for Boston begynde undervisningen ved et beskedent college, som var spiren til det nu så berømte Harvard University i Cambridge, som Newtown kom til at hedde netop for at markere, at det var et nyt lardomssade, man grundlagde.

Få uger for Harvard College åbnede sine porte, kunne man i Londons dokker se det gode skib John of London blive gjort klar til en fard over

1) New England's First Fruits, 1643 . 
Atlanten og blive lastet med den ene balle papir efter den anden og med flere store og tunge kasser, der kom fra Holland. Kun få indviede vidste, at disse indeholdt skriftmateriel og andet udstyr til den bogtrykpresse, der skulle blive Nordamerikas forste ${ }^{\mathrm{r}}$ ). Fohn of London ejedes af en velstående købmandsfamilie, Glover, og havde ombord som passager et af slægtens medlemmer, the Reverend Josse Glover, der var ivrig puritaner og allerede nogle år forinden på grund af sin ulydighed overfor visse af den anglikanske kirkes laresætninger og forordninger var kommet på det sorte bræt, blevet suspenderet og i $16{ }_{3} 6$ tvunget til at tage sin afsked. Han anvendte sin ledighed til i samarbejde og forståelse med sine trosfaller på den anden side af havet at forberede oprettelsen af et bogtrykkeri $\mathrm{i}$ den nye verden. Han indkøbte materiel i Amsterdam og engagerede en fingernem låsesmed Stephen Daye og hans sønner, hvorimellem Matthew Daye, til at følge med til Amerika. Selv oplevede han ikke at se sine planer ført ud $i$ livet, han døde under overfarten, men hans enke, Elizabeth Harris, etablerede trykkeriet i Cambridge, og New Englands hæderkronede guvernør John Winthrop kunne i sine annalistiske optegnelser om New Englands historie under omtalen af begivenhederne $i$ den første måned af 1639 ( 0 : marts) notere: „A printing house was begun at Cambridge by one Daye at the charge of Mr. Glover who died on sea hitherward" ${ }^{2}$ ).

Gutenbergs blysoldater var i deres erobringstogt gennem lande og over have nået til Nordamerika, hvor de hurtigt kom i kirkens, forvaltningens og hele det offentlige livs tjeneste. Forst senere, bemærkelsesvardigt sent, blev trykpressen taget $\mathrm{i}$ brug til ikke-officielle, ikke-lokalt prægede arbejder. Med sådanne blev man forsynet fra England.

At man så hurtigt fik etableret et trykkeri i de nordlige kolonier er et vidnesbyrd om pionerernes intellektuelle ekspansionstrang og trang til opposition. Fra hjemlandet var man vant til, at bogtrykkerkunsten blev forfulgt og kontrolleret; på et tidspunkt da man i Vesteuropa havde

s) Om denne foreligger en omfattende litteratur. Den nyeste behandling er ,The Cambridge Press $163^{8-92}$ " udgivet $\mathrm{i} 1945$ af den amerikanske boghistoriker George Parker Winship. Denne bog, hvori er optrykt en stor del af de om trykkeriet bevarede dokumenter m. v., har leveret meget af materialet til narvarende artikel; en rakke oplysninger er dog hentet bl. a. i L. C.Wroth's „The Colonial Printer" 2 d, ed. 1938, i sammes „The Cambridge Press" it „Bookmen's Holiday. Notes and Studies written and gathered in tribute to Harry Miller Lydenberg ", 1943, p. 498-524, samt i C. Evans' American Bibliography, Vol. I (1639-1729), 1903.

2) John Winthrop: A Journal Of the Transactions and Occurrences in the settlement of Massachusetts and the other New England Colonies, from the year 1630 to 1644 , Hartford 1790 , p. 171 . 
trykkerier i næsten enhver støre by, var der i England kun fire byer med egne trykkerier, nemlig London, York, Oxford og Cambridge. Grunden hertil var naturligvis regeringens og kirkens kamp for at hindre oppositionen $i$ at komme til orde, og først i 1695 blev der givet fri bane for oprettelsen af bogtrykkerier. Man ser således det ejendommelige, at små nybyggerbyer i Amerika som Cambridge, Boston og Philadelphia havde bogtrykkerier længe før så gamle og store byer som Liverpool, Birmingham og Leeds.

Det første produkt fra det lille trykkeri i Cambridge var et etbladstryk "The Freeman's Oath", en trykt formular for dem, der erhvervede de fulde borgerrettigheder i New England. Vi kender ikke noget eksemplar, og heller ikke en almanak fra 1639 er bevaret. Af den forste bog, der udgik fra Mrs. Glovers presse, Davids salmer "newly turned to metre“, den berømte "The Whole Book of Psalms" - The Bay Psalm Book -, der for amerikanerne er, hvad Gutenbergbiblen er for europæerne, kendes få eksemplarer. For få år siden erhvervede Yale University Library et eksemplar af bogen; prisen for den var den nette sum af ${ }_{1} 5^{1}$.000 dollars $\left.{ }^{1}\right)$. The Bay Psalm Book må i betragtning af de forhold, hvorunder den blev til, siges at vare typografisk vellykket. Trykkeriets leder Stephen Daye var som nævnt låsesmed og havde ingen typografisk uddannelse, derimod antager man, at hans søn Matthew, der jo fulgte faderen til Amerika og da var ca. 18 år gammel, har haft en vis uddannelse i bogtrykkerfaget, og det er sikkert ham, der blev Cambridge-pressens egentlige mester.

Mrs. Glovers ægtede efter få års enkestand en af de kendte skikkelser i New Englands aldste historie, Harvard College's president Henry Dunster, og på denne måde gik det til, at pressen flyttedes til kollegiet og inden lange blev overtaget af dette.

Fra pressen udgik iøvrigt i fyrrerne en rakke almanakker, prædikener, love, universitetsprogrammer m. v. og i 165 I en ny udgave af Bay Psalm Book. Et betydningsfuldt og særpræget islæt i pressens produktion var imidlertid det, der skyldes "Indianernes Apostel“, Roxbury-presten John Eliot, en fremtradende og tiltalende skikkelse i missionshistorien ${ }^{2}$ ).

Eliot var født ${ }_{1} 60_{4}$ i Essex og tog i ${ }_{1} 622$ sin Bachelor-grad fra Jesus College i det gamle Cambridge, hvorefter han blev knyttet til en skole i Chelmsford som larer i hebraisk og andre gamle sprog. Skolens leder, Thomas Hooker, var ivrig puritaner og påvirkede den unge Eliot så starkt, at han i 1631 fulgte ham til New England for at blive prast der. Efter en kort tid at have virket i Boston blev han prest i Roxbury, en nygrundet koloni nærved Boston. Med stor ildhu gik han op i sin gerning,

1) Times Literary Supplement, 29. marts 1947 .

2) Om ham se bl. a. S. E. Morison: Builders of the Bay Colony, 1930, p. 289-319. 
og ikke mindst optaget blev han af missionsvirksomheden blandt indianerne, hvis land kolonisterne trangte ind $i$, og med hvem de udkampede skånselsløse kampe men også stod $\mathrm{i}$ en vis fredelig forbindelse. I sin iver for at udbrede evangeliet blandt de indfødte blev han varmt støttet af landsmænd i England og også, men mere lunkent, af sine medkolonister; men Eliot så videre end de fleste andre. Han ville ikke alene kristne indianerne, han ville også skaffe dem mere tålelige levevilkår og forsøge at få dem til at "live in a more orderly way amongst us". Det skulle bl. a. ske ved at oprette selvstyrende indianer-landsbyer, hvis indbyggere skulle lære håndværk og landbrug og lare at læse og skrive. En sådan indstilling mødte en ikke ringe modstand hos Eliots omgivelser, der hyldede princippet "A good Indian is a dead Indian" og så på de indfødte som "devilish men who serve nobody but the devil"; man forargedes, når Eliot påstod, at der $\mathrm{i}$ og for sig ikke var noget i vejen for, at Guds røst havde lydt både på engelsk og indiansk!

I Massachusetts var der på Eliots tid fem forskellige indianerstammer, der talte hver sin dialekt af det algonkianske sprog, et sprog som det synes umuligt at lære, men Eliot fik efter den såkaldte Pequot-krig i I 637 , hvor englænderne tog en mangde fanger, hvoraf en del blev solgt som slaver eller tjenere, lejlighed til at få en indianer i huset hos sig. Senere fik han som tjener Job Nesutan, og ved daglig omgang med ham og sit samkvem med indianerne iøvrigt, lykkedes det efterhånden Eliot at lære deres sprog. Han fik formet et skriftsprog og opstillede de grammatikalske love, og i midten af fyrrerne var han i stand til at prædike for de indfodte i deres eget sprog. Hans missionsarbejde fik god fremgang, men han måtte overbevise skeptikere om sin sprogferdighed ved at arrangere hele demonstrationer der viste, at indianerne virkelig forstod ham, når han pradikede for dem eller katekiserede med dem. Eliots arbejde vaktc berettiget opmærksomhed også i det gamle England, og det lykkedes ham her i 1649 at fă oprettet „The Corporation for the Promoting and Propagating of the Gospel of Jesus Christ among the Indians in New England", en sammenslutning, der i årenes lob fik indsamlet store summer til missionsarbejdet i New England, summer der her blev administreret af the Commissioners of the United Colonies in New England.

Eliot var måske nok lidt stridbar, og der var i hvert fald ofte visse kontroverser mellem ham og de to organer; man så med skepsis på Eliots stadige krav om flere penge og mente, at hans godgørenhed måske gik lidt for vidt. Men "Indianernes Apostel" fortsatte ufortrødent, og i 1654 fik han udgivet den forste bog trykt $\mathrm{i}$ det nordamerikanske indianer- 
sprog $\left.{ }^{1}\right)$. Noget eksemplar af den er ikke kendt, men den kom i flere udgaver, og den tredie, der er fra 1669 , kendes i et enkelt eksemplar, der ejes af universitetsbiblioteket i Edinburgh. Af titlen, der lyder: „The Indian Primer; or The way of training up of our Indian Youth in the good knowledge of God, in the knowledge of the Scriptures and in an ability to Reade", ses, at det foruden at være en katekismus er en slags $\mathrm{ABC}$ for indianerne. På det tidspunkt, da bogen udkom for forste gang, var Eliot i fuld gang med at realisere $\mathrm{ct}$ af de store mål, han havde sat sig: en fuldstandig oversattelse af biblen til det algonkianske sprog. Mange mente, at det var mere hensigtsmæssigt at lære indianerne at læse biblen på engelsk, hvad der dog stred direkte mod Eliots hele missionspolitik, mens andre mente, at opgaven var umulig at lose, i hvert fald for Eliot. For at overbevise skeptikerne fik han i 1655 trykt en prøveoversættelse af Matthæus-evangeliet og af Genesis. Af den forste kendes intet eksemplar, men af Genesis blev et eksemplar fundet i 1937 af John Eliots fremragende bibliograf, den kendte amerikanske boghistoriker Wilberforce Eames. I $165^{8}$ havde Eliot hele bibeloversattelsen fardig.

Det er ikke her stedet at gå ind på spørgsmålet om oversæettelsen betragtet som sprogligt mindesmærke; at den også $\mathrm{i}$ så henseende er meget vardifuld, siger sig selv, og den indtager en fremtrædende plads i den sammenlignende sprogvidenskabs historic. Naturligvis kan oversattelsen ikke stå sig fuldt ud mod en moderne filologisk kritik, men năr det har varet hævdet, at indianerne ikke forstod biblens ord i den Eliotske sprogdragt, er det sikkert ikke rigtigt. Moderne specialister i indianersprog har rost den som varende så god som nogen anden oversættelse, der gennem tiderne har været foretaget til et primitivt sprog, som ikke tidligere overhovedet havde varet skrevet, og endnu mindre trykt, og den dialekt den var skrevet i - Natick dialekten - blev utvivlsomt forstået af de indianerstammer, som levede i New England. Af den nedennæunte anden udgave af biblen fra 1680'erne er da ogsâ bevaret flere eksemplarer, der bærer spor af at have tilhørt indianere og at have varet flittigt last, ligesom man har vidnesbyrd om, at den Eliotske bibel helt op i slutningen af det 18 . århundrede blev benyttet af indianerne.

$\mathrm{Da}$ Eliot begyndte det kæmpcarbejde, det må have været ene mand at oversatte hele biblen til indiansk, troede han ikke selv på, at det skulle lykkes ham at se den trykt, men det gik bedre, end han havde

1) Om denne og Eliots andre indianske bøger se Wilberforce Eames' rigt annoterede bibliografi: Bibliographic Notes on Eliot's Indian Bible and on his other translations and works in the Indian language of Massachusetts, Wash. 1890 . (Sartryk af J. C. Pilling's Bibliography of the Algonquian Languages, 1891). 
ventet, og i 1659 blev der af selskabet i London bevilget de fornødne penge til arbejdet. Men endnu en hindring dukkede op. Cromwells død i 1658 og den efterfolgende "restauration " medforte blandt meget andet, at bibelselskabet blev ophævet, men Eliots forkæmper, den bekendte Richard Baxter fik selskabet reorganiseret under navnet "Society or Company for the Propagation of the Gospel in New England and the parts adjacent", der fik kongelig godkendelse i 1662 og iøvrigt eksisterer den dag i dag. Reorganisationen medforte imidlertid ikke noget afbræk i forberedelserne til og selve trykningen af den indianske bibel.

En forudsatning for, at det store trykkearbejde kunne udføres i Cambridge, var, at trykkeriet dèr, hvis materiel ikke var blevet fornyet eller suppleret siden oprettelsen, blev udvidet. Fra England bestilte man fra et hollandsk skriftstøberi det særlige skriftmateriel, der skulle til, bl.a. den særlige logotype $\infty$ og et ekstra stort antal af typerne $k$ og q, som er så dominerende $\mathrm{i}$ det algonkianske sprog. Man indkøbte også en ny presse og engagerede en uddannet bogtrykker, Marmaduke Johnson, der tilhørte en kendt boghandlerfamilie i London. Onde tunger ville vide, at hans motiv til at tage til Amerika var onsket om at slippe vak fra sin kone, men hvorom alting er, i april 1660 skriver han under på, at han vil tage til Cambridge og blive der $i$ tre år for en årlig løn af $40 £$, hvortil kom "good and sufficient meat, drinking, washing and lodging", og "do and use his best endeavor, art, skill, and knowledge as well in setting as in all other works and employments touching the printing of the said Bible and other books aforesaid. And shall work twelve hours in every day at the least in the same employment (Sabbath days excepted) ....".

Få måneder efter var Johnson i Cambridge og sammen med Samuel Green gik han i gang med bibelarbejdet. Green havde efter Matthew Daye's død i 1649 overtaget ledelsen af trykkeriet, eftersom, there was none in the country to carry it along", og meget tyder på, at også en oplært indianer blev ansat som hjælper, og hjælp kunne nok behøves, det var jo en mildest talt meget fremmedartet tekst, man skulle satte og lase korrektur på. Hvad mener man f. eks. om følgende tilfældigt udvalgte linier:

Kah ahquoantamaiinnean nummatcheseonganonash, newutche nenawun wonk nutahquoantamauóunnonog nishnoh pasuk noonamontukquohwhonan, kah ahque sagkompagninnean en qutchehettuonganit, qut pohquawussinnean wutch matchitut. (Lukasevangeliets 1 I. kapitel, vers 4.$)^{\mathrm{x}}$ )

x) Og forlad os vore synder, thi også vi forlader enhver, som er skyldig over for os; led os ikke ind $\mathrm{i}$ fristelse, og fri os fra det onde! 
Skønt et sjaldent godt kildemateriale tillader os at følge trykningen af biblen måned for måned, må det her være tilstrækkeligt at nævne, at man ved starten regnede med at kunne satte og trykke et ark om ugen. Hvor store tekniske vanskeligheder man måtte overvinde, vil enhver fagmand kunne forstå, i betragtning af at man sikkert kun har haft typemateriel til fire ark, således at man måtte lægge satsen til hvert ark af umiddelbart efter trykningen for at kunne gå i gang med at sætte det næste; alligevel kunne man i sommeren $166 \mathrm{r}$ slutte trykningen af det nye testamente og gå i gang med det gamle testamente. Trykningen af dette og den metriske oversættelse af Davids salmer, der sammen med et enkelt blad indeholdende nogle leveregler afslutter den Eliotske bibel, varede et par år, sâledes at hele bibelværket var færdigt $\mathrm{i}$ eftersommeren 1663, og da havde de mand, der betjente trykkeriets to presser, ca. 175.000 gange presset den tunge digel mod trykformen, idet selve biblen blev trykt $\mathrm{i}$ et oplag på ca. Iooo, mens det nye testamente blev trykt $\mathrm{i}$ I500 eksemplarer, hvoraf de 500 blev udgivet separat, og af disse blev i det mindste 40 forsynet med engelsk titelblad og dedikation.

Under trykningen af det gamle testamente, nærmere bestemt i oktober $166 \mathrm{r}$, indtraf en begivenhed, som truede med at standse eller i hvert fald alvorligt forsinke bibelarbejdet. Marmaduke Johnson, der havde boet hos Samuel Green siden sin ankomst, blev da ikke alene forment enhver adgang til det Greenske hjem, men blev stillet for retten anklaget for forsøg på at „obtain the affections of Elizabeth Green “, Samuels datter, og hvad værre var, til trods for faderens forbud at have fortsat sit måske ikke helt uvelkomne kurmageri til Elizabeth, idet han tog ,all opportunityes to get in to her company comeing into ye yard in the evening time \& divers times did send for her to $\mathrm{Wm}$ Barratts, where they were often together, \& throw his flattering \& allureing expressions shee was greatly insnared by him, for the wch she seeht now case to lament her own folly \& to blesse the Lord that hath deliverd her from so great a snare". Elizabeth Green gik under et af de senere forhør mere i detailler og fortalte, at hun havde holdt stævnemøde med den unge Johnson i Barratts hus ,where they were together in the house alone sundry hours, \& ye sd Johnson did much importune her to ingage her selfe to him by a sollem promise of mariage". I betragtning af, at Johnson som nævnt havde en kone siddende i London, var hans adfard naturligvis i skarende modstrid med den puritanske moral og også med koloniens love, og han blev idømt en bøde på ikke mindre end $25 \mathrm{f}$. Da han ikke kunne betale, måtte han „continue in prison untill his fine be sattisfied, \& security given for his good behavior". Men selv om måske 
ingen havde medlidenhed med Johnson, så var han en vigtig betingelse for, at trykningen af biblen kunne blive fardig i rette tid, og både den vrede fader og John Eliot blev betankelige, da Johnson havde været vak fra trykkeriet et halvt års tid, og bibelarbejdet blev svart forsinket; visse krafter blev derfor sat $i$ gang, og selv om retten $i$ april 1662 giver blankt afslag på Johnsons bon om at komme på fri fod, så finder vi ham alligevel ganske kort tid efter tilbage i trykkeriet, hvor han jo unæg teligt også gjorde mere nytte end $\mathrm{i}$ fængslet, og hvad mere bemærkelsesvardigt er, Samuel Green tager ham igen i sit hus, som om intet var handt, men det er sandsynligt, at den ombejlede Elizabeth nu opholdt sig uden for rakkevidde!

Efter at Johnson igen var kommet $\mathrm{i}$ arbejde, blev tempoet $\mathrm{i}$ trykkeriet sat betydeligt op, så man indvandt den tabte tid, og i efteråret $166_{3}$, tre år og nogle få uger efter at arbejdet var begyndt, var det ca. 1200 sider store værk færdigt fra pressen, og de beregninger, der som navnt var gjort for man gik i gang, hvorefter, the printers doubt not but to print a sheet every weeke and compute the whole to amount a hundred and fifty sheets", havde vist sig at vare beundringsvardigt pracise.

Af den Eliotske bibel, den forste bibel trykt uden for Europa, er, i forhold til oplagets storrelse - kun fâ eksemplarer, såvidt man ved ca. $6 \mathrm{o}$, bevaret. Bibliografisk kan de, når hensyn tages til antallet af titelblade, tilstedevarelse af dedikation m. v., klassificeres i 7 forskellige grupper. Det kongelige Bibliotek ejer et eksemplar, der tilhører den tredie gruppe, og da det ikke er omtalt $i$ den rige litteratur om Cambridgepressen eller i Eames' og Evans' lister over eksisterende eksemplarer, skal her gives en nærmere beskrivelse af det:

Bl. I: tomt.

Bl. 2: Titelblad med engelsk titel til hele biblen, ramme sammensat af agern-røskener (se illustrationen).

Bl. 3-4 (med arksignatur $\left.\mathrm{A}_{3}-4\right)$ : Dedikation fra The Commissioners of the United Colonies in New England til kong Karl II.

Bl. 5 a: tomt.

Bl. 5 b: Indholdsoversigt på algonkiansk til hele biblen.

Bl. 6-419 (med arksignatur (hvori enkelte trykfejl) A-Mmmmm 2): Det gamle testamentes tekst.

Bl. 420: Titelblad i samme ramme som bl. 2. På sidens nederste halvdel mellem to vandrette linier findes en rombeformet vignet sammensat af røskener i otte linier. Bagsiden tom.

Titel: WUSKU / WUTTESTAMENTUM / NUL-LORDUMUN / 


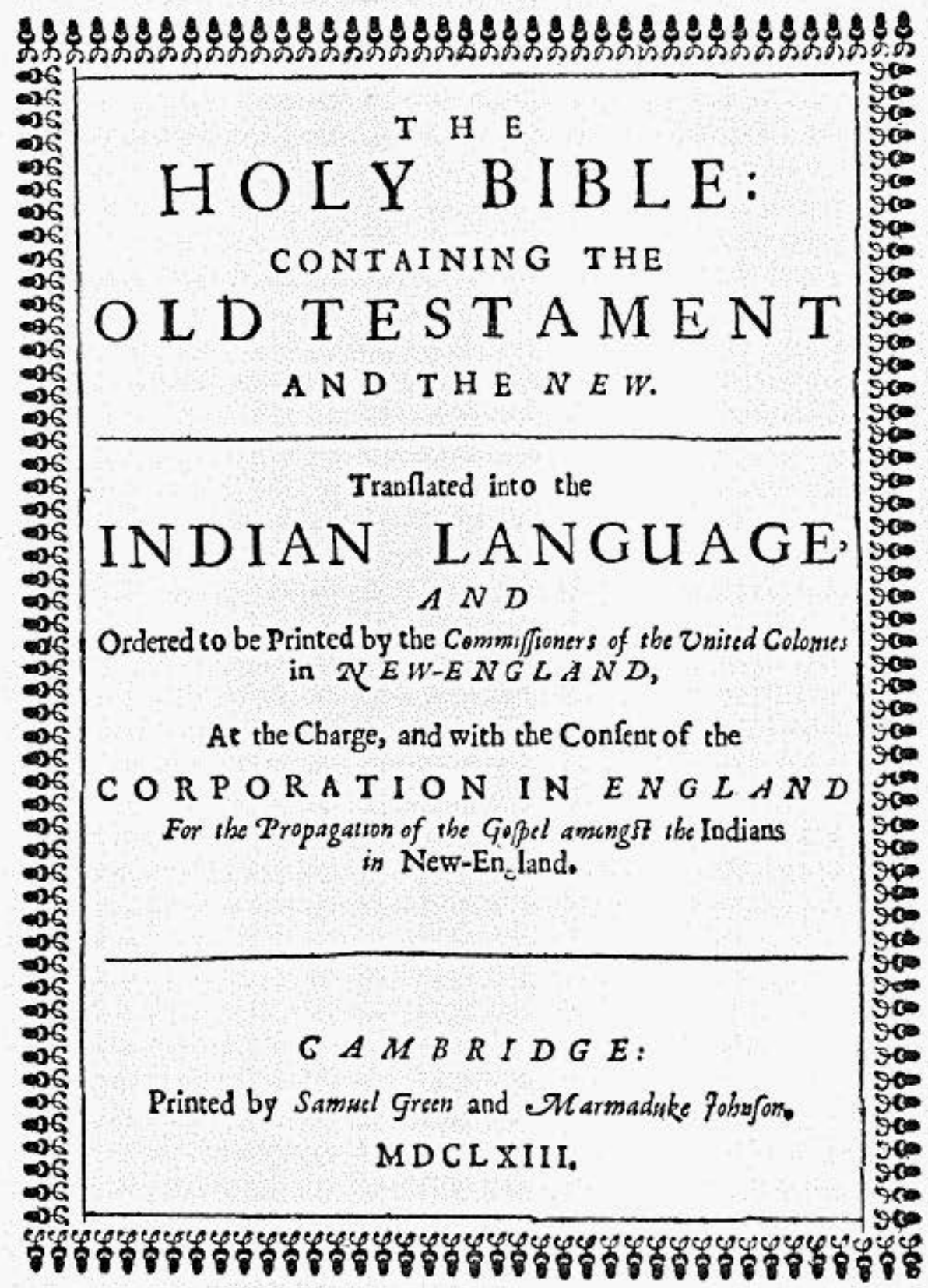

Titelblad til 1, udgave af biblen oversat til det indianske sprog af John Eliot, trykt i Cambridge, Mass. $166 \mathrm{i}-63$. 
JESUS CHRIST / Nuppoquowhussuaeneumun. / [Nyt / hans testamente / vorherre / Jesus Kristus / vor frelser.]

(Vignet) GAMBRIDGE: Printed by Samuel Green and Marmaduke fohnson. / MDCLXI.

Bl. $42 \mathrm{I}-463$ (med arksignatur $\mathrm{A}_{2}-\mathrm{L}_{4}$ ): Matthæus-, Markus- og Lukasevangeliet.

Bl. $464-546$ (med arksignatur Aa-Xx 3 ): Resten af det ny testamente.

Bl. 547 : tomt.

B1. 548-597 (med arksignatur A-N2): VVAME / Ketoohomae uketoohomaongash / DAVID / [Alle Davids syngende sange].

Bl. $59^{8}$ : Kristne leveregler.

Bl. 599: tomt.

Bogens format er kvart, og det foreliggende eksemplar måler $190 \times$ $148 \mathrm{~mm}$ (eller $7^{4 / 8} \times 5^{13 / 16}$ inches), således at det er omtrent lige så stort som det storste eksemplar, der findes beskrevet af Wilberforce Eames (bibliografiens no. ${ }_{15}$, der måler $7^{5 / 8} \times 5^{7 / 8}$ inches). Som brødskrift er anvendt en type på 8 punkt, der svarer til vores petit, men dengang kaldtes brevier. Skriftsnittet er antikva og er nasten det samme som findes i det typemateriel biskop Fell i ${ }_{1} 6_{72}$ indkøbte i Holland til Oxford University Press. Trykkeriet rådede over otte forskellige grader fra en 24 pkt. dobbelt pica til en nonpareil på 6 pkt., og alle grader findes reprasenteret i biblen. Teksten er trykt dobbeltspaltet med levende kolumnetitel. Antallet af typeenheder pr. side er ca. $4500 \mathrm{og}$ linietallet pr. spalte normalt 62 , men i det nye testamentes ark I, $\mathrm{K}$ og L er tallet sine steder $6_{3}$ og $6_{4}$. Denne variation står i forbindelse med det forhold, at der inden for dette afsnit af biblen er to arksignaturer, $\mathrm{A}-\mathrm{L}$ og $\mathrm{Aa}-\mathrm{Xx}$; det må skyldes, at to sættere samtidigt er begyndt på hver sin del af det nye testamente. Man antager, at Johnson er mester for den sidste del $(\mathrm{Aa}-\mathrm{Xx})$, mens Green har udført de første ark. For at være sikker på at slutte ved udgangen af et ark har denne på de sidste sider af Lukasevangeliet måttet forøge linietallet. Der er iøvrigt visse forskelle mellem trykket $\mathrm{i}$ arkene med de to forskellige alfabetsignaturer, således $\mathrm{i}$ kolumnetitlen, og Johnson indleder sit afsnit (Johannes-evangeliet og ud) med en røskenfrise og et traskåret (klichéret) initial, mens hverken Markuseller Lukas-evangeliet har en sådan indledning. Endvidere er der i den sidste del $\mathrm{i}$ vid udstrakning anvendt logotypen oo i kursiv, sikkert af mangel på normale typer. Som initialer er i almindelighed anvendt store majuskler, men på bl. $\mathrm{A}_{\mathrm{I}} \mathrm{i}$ det gamle testamente og på bl. A2, AaI, Dd (verso) i det nye samt på bl. Aı i Davids salmer findes større 
traskårne (klichérede) initialer på blomstret baggrund. Initialet på bl. Dd er spejlvendt. Dedikationen indledes med et passepartout-initial. På de samme sider på hvilke der findes store initialer, findes også røskenfriser, hvoraf de to sidst forekommende er ens. Biblen er overalt forsynet med kustoder, og i testamenterne findes noter i begge marginer; henvisningerne til dem sker ved hjælp af et lille kursivbogstav indsat foran det pågxldende ord $\mathrm{i}$ teksten.

Det kongelige Biblioteks eksemplar er bemærkelsesvardigt derved, at det ikke har den ellers almindeligvis forekommende trykfejl i kolumnetitlen på recto-siderne af bl. $\mathrm{L}_{2}$ og $\mathrm{L}_{4}$, nemlig "Chap. I0 " og "Chap. $5_{5}$ " i stedet for "Chap. 2 I " og "Chap. 24". Fejlen må være blevet opdaget under trykningen og rettet $\mathrm{i}$ den sidste del af oplaget.

Det papir biblen blev trykt på, blev indkøbt i flere omgange og sendt fra England til New England, der endnu ikke havde nogen papirmølle. Kvaliteten er da også noget forskellig $\mathrm{i}$ de forskellige dele af biblen, ligesom der forekommer flere forskellige vandmærker. Til biblen blev indkøbt ialt 368 ris papir, men til selve de færdige eksemplarer er kun medgået 327 , således at over 40 ris er gået til korrekturaftryk m. v. Trykkets kvalitet veksler noget, men som helhed må det siges, at den Eliotske bibel er udmærket håndvark og slet ikke præget af det hastige og tilfældige, som karakteriserer så mange andre missionstryk. Titelbladene er godt komponerede med en sikker brug af typer og ornamenter.

Størstedelen af biblens oplag var naturligvis bestemt til at skulle uddeles blandt de indfødte og har derfor kun indianske titelblade, men en del af oplaget blev forsynet med engelsk titelblad til hele biblen og med en engelsk fortale, og Det kongelige Biblioteks eksemplar tilhører denne del af oplaget. Naturligvis skulle der bruges en del eksemplarer til uddeling i England bl. a. til medlemmerne af det tidligere omtalte New England Company, der financierede trykningen. Disse dedikationseksemplarer blev indbundet i morkeblåt maroquin ved London-boghandleren Samuel Gellibrands formidling, og i april $166_{4}$ overrakte præsidenten for selskabet, Robert Boyle, kongen et eksemplar, men audiensen blev brat afbrudt, da der kom en ekstraordinær envoyé, som krævede kongens øjeblikkelige nærværelse og, skriver Boyle, ,hindred me from receiving that fuller expression of his grace toward the translators and Dedicators that might otherwise have been expected".

Der er meget, der tyder på, at Det kongelige Biblioteks eksemplar af biblen er et af disse dedikationseksemplarer; $i$ hvert fald er det meget fornemt indbundet, i mørkeblăt, næesten sort, maroquin og med en overdådig forgyldning på sider og ryg, med randbordurer m. v. På ryggen 
findes seks agte bind, og bogen har iøvrigt $\mathrm{i}$ sin tid varet forsynet med blå silkebånd til at holde bindet sammen. Alle tre snit er forgyldte, og beskæringen er så skånsom, at høvlen især på undersnittet $\mathrm{i}$ mange tilfælde ikke har rørt bladene. Forsatspapiret er kammarmor og udført i rodt, gult, blåt og hvidt.

Iøvrigt blev en del af oplaget indbundet af Boston-bogbinderen John Ratcliff, ligesom også Samuel Green påtog sig at indbinde et par hundrede eksemplarer. Af disse i samtidige amerikanske bind indbundne eksemplarer kendes nu kun tre eksemplarer, medens man mener at kunne identificere fire af de eksemplarer, man til gavebrug lod den ovennavnte Gellibrand indbinde hos en eller flere bogbindere i London. Er Det kongelige Biblioteks Eliotbibel et femte gaveeksemplar i originalt bind, er dets vardi i dag meget stor, men selv om det ikke skulle vare tilfældet, er den alligevel $\mathrm{i}$ betragtning af sit samtidige bind $\mathrm{og}$ komplette tilstand en stor kostbarhed, og det var billigt når biblioteket i sin tid erhvervede det for 2 mark, eller en krones sølvvardi!

Der kan nemlig ikke vare tvivl om, at biblen stammer fra det berømte Thottske bibliotek, det storste og mest alsidige privatbibliotek, der nogensinde har været her i Danmark. Efter Otto Thotts død i i 785 blev hans næsten 200.000 bind store bibliotek, efter at Det kongelige Bibliotek som gave havde modtaget alle håndskrifter og bøger trykt for ${ }_{1} 530$, som bekendt solgt ved en rakke auktioner - og til skandaløst lave priser. I auktionskatalogen fra $\mathrm{I} 789$, Bd. I, part $\mathrm{I}, \mathrm{s} . \mathrm{I} 04$ findes under gruppen Biblia Americana som nummer 2354 følgende: „Biblia in linguam Indicam s. Virginianam translata a Jo. Eliot, dicata Carolo II. Regi Angliae. Cantabrig. in Nova Anglia typ. Sam.Green. 661-63. t. [egumentum] c.[ori]o T.[urcico] n.[igro] fol.[ia] aur.[ata]". Af det i Universitetsbiblioteket opbevarede eksemplar af auktionskatalogen, der er forsynet med priser og købernavne, fremgår, at Det kongelige Bibliotek erhvervede bogen for de ovennavnte 2 mark. Det er således Otto Thotts fanomenale samleiver og bogkendskab vi kan takke for, at biblioteket ejer denne og mange andre - virkelige sjældenheder.

Hvorfra Thott har erhvervet bogen, får man straks en anelse om, når man ser på biblens friblad; øverst oppe står nemlig med blyantskrift en prisangivelse „-12 - "skrevet med en hånd, som kendes fra mange andre af Thotts bøger: den kendte London-boghandler Thomas Osborne's. Af ham købte Thott flere hundrede bøger stammende fra det berømte Harley'ske bibliotek, som Osborne realiserede i årene $1743-45$, og hvorover han udgav en fem bind stor katalog. I Catalogus Bibliothecae Harleianac, Vol. III, London 1744 findes på side $39^{8}$ under afsnittet 


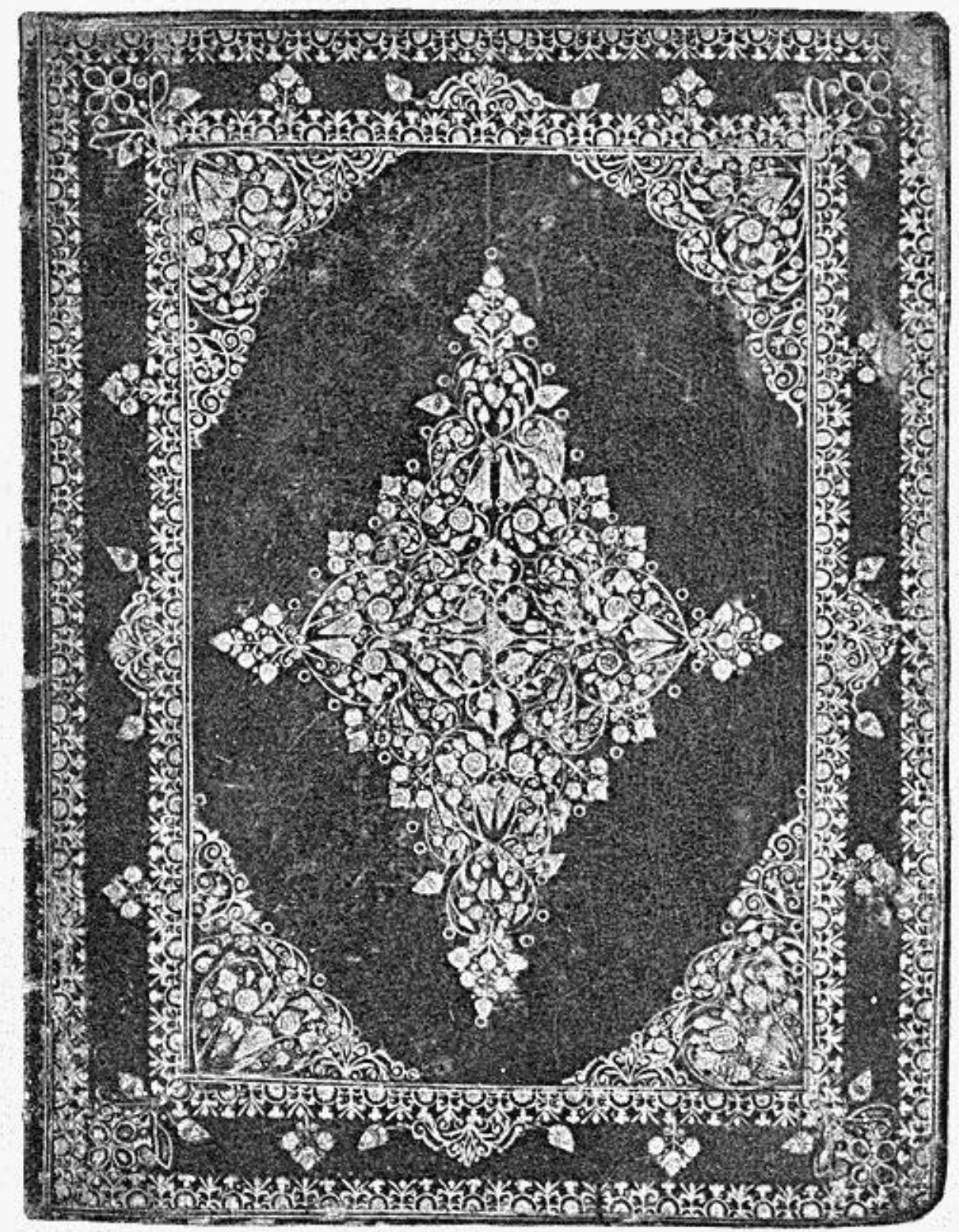

Forsiden af det morkeblá, nasten helt sorte maroquinbind om Det kongelige Biblioteks eksemplar af den Eliotske bibel, trykt i Cambridge $1661-63$. Originalens storrelse $19,7 \times 15 \mathrm{~cm}$. 
English Divinity \&c. Quarto, „7 rog. Holy Bible in the Indian Language, I663", og selv om det må undre, at der ikke er bemærket noget om eksemplarets fine beskaffenhed, er der næppe grund til at tvivle om, at det er Det kongelige Biblioteks bibel, der er tale om. Familien Harley er kendt for sine bibliofile interesser, der kulminerede under Robert Harley (166I-1724) og sønnen Edward Harley, efter hvis død $174 \mathrm{I}$ det store bibliotek blev solgt til Thomas Osborne').

Hvor lange det foreliggende eksemplar af den Eliotske bibel har varet i Bibliotheca Harleiana, kan nappe opklares, det har i hvert fald været på andre hænder, før det nåede her. På fribladet findes, hvad der synes at være en ejerantegnelse, nemlig i øverste højre hjørne bogstaverne K L M og i linien nedenunder Pr. I5 eller Pr. ${ }_{5}$. Det drejer sig muligvis om en bibliotekssignatur, og det samme er vel de bogstaver mu anbragt på en brøkstreg med n som nævner, der er skrevet i øverste hjørne af forsatsbladets bagside. Bogens forperm er omtrent helt oppe forsynet med en lille påklistret seddel, der går 6-7 mm ind på bindets inderside, omkring bindets kant og et par $\mathrm{mm}$ ind på selve bindets forside; på den indvendige del af markesedlen ses oven over hinanden to bogstaver, der kan læses som $10 g$ g eller $\mathrm{s}$ og $\mathrm{g}$ (Samuel Gellibrand?). Sandsynligvis er der dog tale om en pladssignatur.

Fuldførelsen af den indianske bibel var en triumf for John Eliot og en sejr over dem, der havde stillet sig tvivlende over for hans foretagende, og den følgende halve snes âr blev sikkert hans lykkeligste. Han fik udgivet forskellige andre værker på algonkiansk bl. a., den tidligere nævnte udgave af "The Indian Primer" (1669), Rich. Baxters beromte "Call to the Unconverted“ (1664), Lewis Baylys "Practice of Piety “ (1665) og „The Indian Grammar" (1666). Antallet af omvendte voksede, og Eliot og hans hjælper Daniel Gookin, der i 1656 blev den forste prast for de indianske menigheder, fik oprettet en rakke af de særlig selvstyrende indianerlandsbyer, og her holdt Eliot ,sommerkurser" i teologi, logik og klassisk litteratur! Naturligvis led han også skuffelser, men han havde alligevel mere held end Harvard College, der ved at oprette et særligt Indian College søgte at lare indianerne den europaiske kultur. Af de fâ unge indianere, der søgte optagelse, var der dog kun en, der fuldførte studiet, og han døde desvarre året efter. Hans navn var Caleb Cheeshateaumuck, den eneste indianer, der har opnået eksamen fra Harvard universitetet.

Den såkaldte kong Philips krig, ${ }_{675}-76$, betød en katastrofe for John Eliot og hans missionsarbejde. Krigen blev startet af høvdingen $\left.{ }^{2}\right)$ Se bl. a. W. Y. Fletcher: English Book Collectors, 1902, p. 150-56. 
Sachem'en - for Pokanoket- og Wampanoag-indianerne. Eliot havde tidligere forsøgt at kristne også disse stammer, men forgaves, og det fortalles, at Philip efter at have lyttet til Eliots prodiken gik hen til ham og tog fat $\mathrm{i}$ en knap $\mathrm{i}$ hans frakke og sagde, at han brød sig lige så lidt om evangeliet som om Eliots knap!

Da kampene med indianerne begyndte, blev de Eliotske indianerlandsbyer rømmet, skønt Eliot forsikrede, at deres indbyggere stod på de hvides side mod deres stammefrander. Indianerne i landsbyerne blev i huj og hast deporteret til en ø uden for Boston, hvor mange døde på grund af vanrøgt. Eliot og Gookin gjorde hvad de kunne for at hjælpe, men blev mødt med megen kulde og direkte modstand fra englændernes side, og deres protester mod at tilfangetagne indianere blev solgt som slaver, blev der heller ikke taget hensyn til. Senere i krigens slutning fik en del af de internerede indianere dog lov til at kampe på de hvides side, og det var en af disse loyale indianere, der drabte kong Philip.

$\mathrm{Da}$ freden var sluttet, måtte den ikke længere unge John Eliot $\mathrm{i}$ gang med at bygge op, hvad krigen havde ødelagt, og han skriver i sin kirkebog: „When the Indians were hurried away to an Iland at half an hours warning, pore soules in terror yei left theire goods, books, bibles, only some few carried yr Bibles, the rest were spoyled \& lost. So yt when ye wares wre finished, \& yei espicially bewailed yr want of Bibles, ys made me meditate upon a $2 \mathrm{~d}$ impression of o'r Bible, \& accordingly tooke paines to revise the first edition".

Til hjælp ved oversættelsen fik han en afskediget prast John Cotton, der var meget kyndig $\mathrm{i}$ det indianske sprog og især i nogle dialekter, som Eliot ikke var så fortrolig med, så hele bibelteksten gennemgik en meget grundig og nyttig revision. Efter at Eliot overfor New England-kompagniet i London havde berettet om, hvordan indianerne ,beg, cry, entreat for bibles", lykkedes det at få kompagniets støtte til en ny udgave.

Den forelå ferdig i 1685 og var trykt af Samuel Green, idet Marmaduke Johnson var død i 1674 , efter at han i 1665 havde fảet sit eget trykkeri og de følgende år dels konkurrerede med og dels til tider samarbejdede med Green.

Af denne anden udgave, der blev trykt $\mathrm{i}$ et oplag på 200o, er kun et fåtal bevaret, men også af denne ejer Det kongelige Bibliotek et eksemplar. Det er muligt, at også det stammer fra det Thottske bibliotek, i hvert fald har Otto Thott haft bogen, men efter auktionskatalogen skulle den vare solgt til Universitetsbiblioteket, der imidlertid ikke ejer værket, så det er muligt, at det er det Thottske eksemplar, der er nået til Det kongelige Bibliotek. 
Eksemplaret er ikke ganske komplet, idet de tre sidste blade mangler, og en kortfattet kollationering ser således ud:

Bl. I: tomt.

Bl. 2: Titelblad i stregramme og ramme sammensat af agern- og fleurde-lis-røskener og med titel: MAMUSSE / WUNNEETUPANATAMWE / UP-BIBLUM GOD / NANEESWE / NUKKONE TESTAMENT/KAH WONK/WUSKU TESTAMENT./Ne quoshkinnumuk nashpe Wuttinneumoh CHRIST/noh asoowesit / JOHN ELIOT. / Nahohtôeu ontchetôe Printenœomuk / CAMBRIDGE. / Printeuøop nashpe Samuel Green. MDCLXXXV. [o: Hele / hellige / Guds bibel / både/gamle testamente/og også/nye testamente./Oversat af tjeneren af Christus / ved navn / John Eliot / Anden forogede udgave. Cambridge. / Trykt af Samuel Green. 1685].

Bl. 3-427 (m. arksignatur A-Ppppp $)$ : Det gamle testamente.

Bl. 428 a: tomt.

Bl. $428 \mathrm{~b}$ : Indholdsoversigt over hele biblen.

Bl. 429: Titelblad i røskenramme med titel: VVUSKU / WUTTESTAMENTUM/NUL-LORDUMUN/IESUS CHRIST/Nuppoquohwussuaeneumun. / CAMBRIDGE, Printed for the Right Honourable / CORPORATION in London, for the / propogation [!] of the Gospel among the In- / dians in New-England 1680.

Bl. $43^{0}-605$ (m. arksignatur A 2-Yy): Det nye testamente og Davids salmer. Bl. 6o6-6o8: mangler.

Biblen er trykt med det samme materiel og i det store og hele på samme måde som forsteudgaven, dog er der foran hvert kapitel indføjet et ganske kort engelsk resumé af indholdet. Eksemplaret, der er et af dem, der skulle spredes blandt indianerne, er indbundet $\mathrm{i}$ et ret dårligt udfort kalveskindsbind uden ornamenter, bortset fra blindtrykte linier langs ryggens fire agte bind. Der kan næppe være tvivl om, at bindet er udført i New England umiddelbart efter udgivelsen, idet det da blev købt af et af de store navne i Massachusetts' historie, købmanden Joshua Scottow, der som barn eller som ganske ung sammen med sin moder, der var enke, og sin broder, Thomas, krydsede Atlanterhavet på et af de første udvandrerskibe. Scottow udgav et par småskrifter, hvoraf det ene, "Narrative of the Planting of the Massachusetts Colony, Anno I628", udkom anonymt $\mathrm{r} 694$ fire år før Scottow døde 80 år gammel ${ }^{1}$ ).

1) Optrykt i Collections of the Massachusetts Historical Society, 4 . ser. Vol. 4, 1858, p. 279-330. Om Scottow se bl. a. sstds., 2. ser. Vol. 4, 1816, reprinted 1846, p. 100-104. 
Eliotbiblen havde han dog allerede i 1686 skenket til en af sine landsmand, der bagpå fribladet skrev: Ex dono Mr. Joshua Scottow. 1686. / George Burrough his bible. Den nye ejermand er utvivlsomt den for sin tragiske skabne bekendte prest i Falmouth, George Burroughs ${ }^{1}$ ), der den 19. august $169^{2}, 4^{2}$ år gammel, blev henrettet for trolddom. Han blev et af de mange ofre for de fanatiske og uhyggelige hekseprocesser, som da fandt sted i Salem.

Hvordan Eliotbiblen fra Falmouth er kommet til Danmark, lader sig ikke efterspore. På fribladets Forside står foruden en prisangivelse, $7 / 9^{\prime \prime}$ (?)

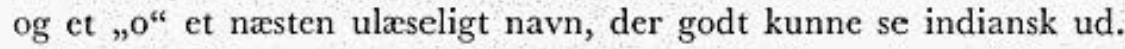

Da John Eliot med stolthed kunne notere fardiggørelsen af den anden udgave af sit mestervark, bibeloversattelsen, var han en gammel mand. Han kunne se tilbage på et langt liv i sejgt arbejde for at kristne og hjælpe "people without Law, without Letters, without Riches, or Means to procure any such thing; a People that sate as deep in Darkness, and in the shadow of Death, as (we think) any since the Creation "z). Hans arbejde havde på mange måder båret god frugt, og hans mistrøstige udtalelser i 1651 "I have no hope to see the Bible translated, much less printed in my dayes" var blevet gjort grundigt til skamme.

I sine sidste leveår opnåede han at få nedennæunte tre indianske bøger udgivet, men i 1690 var hans krafter udtomte; den 21 . maj dette år døde han $\mathrm{i}$ Roxbury, hvis sjalehyrde han havde været $\mathrm{i}$ mere end et halvt århundrede.

De to sjaldne indianske bibler i Det kongelige Bibliotek fortaller os meget om en såre interessant epoke $i$ den vestlige kulturs historie og giver os mange bidrag til Nordamerikas forste bogtrykkeris historie.

Højdepunkterne heri var netop trykningen af de indianske bibler, og også trykkeriets sidste år stod $\mathrm{i}$ indianermissionens tegn. $\mathrm{r} 687$ tryktes en ny udgave af Eliots „Indian Primer“, næste år en anden udgave af hans oversættelse af Baxters "Call to the Unconverted", I689 kom Thomas Shepards "Sincere Convert", oversat til indianersproget, ligeledes af John Eliot, og 1691 trykte Samuel Green og hans son Bartholomew en oversættelse af John Cottons „Spiritual Milk for Babes, drawn from the Breasts of both Testaments". Da var Samuel Green en gammel mand, der havde ledet Cambridge-pressen $\mathrm{i}$ over fyrretyve år, og skont han havde flere sonner, der gik $\mathrm{i}$ hans fodspor som bogtrykkere, onskede ingen af dem at fortsatte faderens trykkeri; de sogte til Boston, der nu

1) Appletons' Cyclopæedia of American Biography, Vol. I, 1887 , p. 470.

2) Fortalen til 1663 -udgaven af biblen, p. (2). 
var blevet hovedbyen i Massachusetts. Det sidste større værk, vi kender fra Samuel Greens værksted, er Cotton Mathers „Ornaments for the daughters of Zion. Or the character and happiness of a vertous woman", 1692. Få måneder efter blev trykkeriet nedlagt, og Bartholomew Green tog med sig til Boston, hvad han kunne bruge til sit trykkeri der. En del fa det materiel, som stammede fra trykkeriets grundlaggelse i 1639 , har man sikkert ikke ment det umagen vard at flytte med, og det er blevet tilbage i det såkaldte Indian College i Harvard universitetets gård, hvor trykkeriet havde til huse. I hvert fald har man fundet to Harvardstudenter, Walter Price's og Joseph Mors' exlibris, trykt i 1693 med materiel, der stammer helt tilbage til Stephen Daye's tid.

Cambridge-trykkeriets halvthundredârige historie er historien om Nordamerikas „inkunabeltid“; dets omfattende betydning for det lille samfund i den nye verden er det ikke her stedet nærmere at behandle, det må være tilstrækkeligt at citere, hvad en førende amerikansk boghistoriker L. C.Wroth skriver i Hellmut Lehmann-Haupts vark om "The Book in America" (2d ed., 1951): "No other press of the whole colonial period partook to the same degree of the qualities of the learned presses of Europe, or maintained so successfully the great traditions of the craft as an intellectual force in the midst of a new and rude environment. Its inability to show the production of any work of imaginative secular literature was not an item in its discredit. In New England, and elsewhere in a country of laborious living, that particular flower of the spirit came to blossom only in the relative leisure of the next century. Nor did that press concern itself to any extent with material affairs of the people, with the farming, fishing, buying, selling, and building by which they lived. It had been established to advance the work of church and commonwealth. Within that limitation it was a successful concern, surpassing, it may be, the expectations of its founder"). Det er sikkert ganske rigtigt; Josse Glover, presten fra Sutton, forestillede sig næppe, at det beskedne trykkeri, han i ${ }_{1} 6{ }_{3} 8$ tog med sig ombord på John of London, og som han jo iøvrigt ikke oplevede at se i virksomhed, skulle få den indflydelse på samtiden, som det fik, og lagge grunden til den amerikanske bogproduktion, der, ifølge Evans' bibliografi, i ${ }_{17} 83$, da kolonitiden var forbi, var nået op på ialt ca. 18.000 forskellige tryk, og i vore dage er steget til den imponerende højde af, foruden titusinder af tidsskrifter, blade, småtryk o. l., ca. 12.00o egentlige bøger om året. 